\title{
Assessment of Pre-Monsoon and Monsoon Groundwater Level and Fluctuation at Regional Level in South of Haryana; Reference to Rewari District
}

\author{
Surender Kumar*, Mamta Rani, Anurag and Shubham Verma \\ Department of Agricultural Meteorology, CCS Haryana Agricultural University, Hisar, Haryana, India \\ "Corresponding author: surenderchahal299@gmail.com
}

Received: 10 Aug., 2020

Revised: 20 Nov., 2020

Accepted: 29 Nov., 2020

\begin{abstract}
A present study was carried out at Dept. of Agro- Meteorology, CCS HAU Hisar to find the status of ground water in Rewari district for two decades i.e. from 1996-2017 With the main objective to investigate the temporal trends in annual and seasonal groundwater level and fluctuation in Rewari district. The study involved analysis of the ground water data for 20 years and mapped the changed in ground water levels between pre monsoon and monsoon seasons. The major activities in ground water fluctuation in five block of Rewari district involved the of existing data, generation of GIS database (shape files), interpolation, categorization, mapping and interpretation. Trend analysis has been done spatial analysis by Geographical Information Systems (GIS). The results indicated that a mix of negative and positive trends in the groundwater level series. Results also indicated the pre-monsoon ground water level influenced higher recharge of ground water than the total annual amount of rainfall. In pre- Monsoon rise in water level was found in north parts and decline was in south eastern parts. Study show that in Monsoon Central parts of Rewari district observed rising water table and South Eastern and North Western parts of district had declining water level from normal. The pre-monsoon season the groundwater level varied from 7.26 to 22.23 meters below ground level in depth and during the monsoon season the groundwater level was found to be from 10.46 meters to 22.23 meters bgl during year (2017).
\end{abstract}

Keywords: Groundwater level, fluctuation, pre-monsoon and monsoon, average, GIS

Water is one of the most valuable natural resources. Now a days groundwater depletion has been recognized as a global problem and the estimated that global groundwater depletion during 1900-2008 is about $4500 \mathrm{~km}^{3}$ with the maximum rates occurring from 2000 to 2008 (Konikow, 2011). Groundwater 
use for irrigation has intensified around the world. Groundwater-based irrigation is directed to cultivated high-yielding rice during the dry season in South Asia, where India and Bangladesh represent the world's second and fourth biggest rice-producing nations, respectively (Scott and Sharma 2009; IRRI 2010).

According to Fourth Assessment Report (AR IV) of IPCC in India urbanization and industrialization, population growth and inefficient water use cases increase water shortages and its adverse impact son demand, supply and water quality which increase under changing climate (IPCC 2007). Recent studies in India reported that ground water level were decline which indicates unsustainable groundwater abstraction for both irrigation and urban water supplies. The knowledge of groundwater table fluctuations is important in agricultural lands as well as in the studies of its utilization and management levels. Groundwater is the most important water resource in semi-arid and arid regions such as Haryana. In recent years, the rapid growth of population and the increased need for water and food has put its land and water resources under severe stress. Groundwater is a dynamic natural resource. But in hard rock terrains, availability of groundwater is of limited extent. In India, 65 per cent of the total geographical area is covered by hard rock formation with low porosity (less than 5 per cent) and very low permeability (Saraf and Choudhary, 1998).

The Rewari district in Haryana state of India has agriculture based economy. The South West monsoon sets in from last week of June and withdraws in end of September, contributing about $88 \%$ of annual rainfall. July and August are the wettest months. Rest $12 \%$ rainfall is received during non-monsoon period in the wake of western disturbances and thunderstorms. Generally rainfall in the district increases from Southwest to Northeast. The mean minimum and maximum temperature in the area ranges from $5.6^{\circ} \mathrm{C}$ to $41.0^{\circ} \mathrm{C}$ during January and May or June respectively. Hence, availability of groundwater in good quantity is of our most importance for the area; Because of natural physiographic, high population density and intense agricultural activity, the groundwater levels and quality in the district is under high risk. Therefore, the present study was undertaken with an objective to analyse the long term changes in ground water depth and ground water fluctuation with regards to natural conditions prevailing in the area (Anonymous 2013).

\section{Study Area}

Rewari is the Southern district of Haryana state with a total geographical area of $1594 \mathrm{sq} . \mathrm{km}$ and is located between $27^{\circ} 46^{\prime}$ to $28^{\circ} 28^{\prime} \mathrm{N}$ latitude and $76^{\circ} 15^{\prime}$ to $76^{\circ} 51^{\prime} \mathrm{E}$ longitude. The district broadly forms part of Indo-Gangatic alluvial plain of Yamuna sub basin. It has vast alluvial and sandy tracts and interspersed strike ridges which are occasionally covered with blown sand. The district is under control of Gurgaon division and administratively divided into five blocks namely Bawal, Jatushana, Khol, Nahar and Rewari. The main water resource is district is Sahibi and Krisnavati River. In the Western part of is flat and sandy and absorbs all the rainwater. There are various other small nalas also carry rain water from the hills during Monsoon season (Anonymous 2013).

\section{MATERIALS AND METHODS}

The study is analytical in nature and based on secondary sources information. Major sources of data were ground water year data published by Central Ground Water Board and Ground Water Cell, Agricultural Department, Government of Haryana and statistical abstract of Haryana. The study was carried out for period of last 2 decades (1996-2017). Five stations/ground water observations well were selected from each 
block in the Rewari district. The selected observation wells were Jatusana, Sangwari, Lukhi, Karanwas and Aulant falling in Jatusana, Rewari, Nahar, Bawal, and Khol blocks respectively. The major activities involved in this process include compilation of existing data, generation of GIS database (shape files), interpolation, categorization, mapping and interpretation.

\section{RESULTS AND DISCUSSION}

Results of the study are self-explanatory form various maps prepared in the study (Fig. 1 to 5). For better understanding the interpretation was carried out for long period average groundwater level for seasons (pre monsoon and monsoon), current groundwater level i.e. year 2017 and fluctuation of current groundwater level from its long period average.

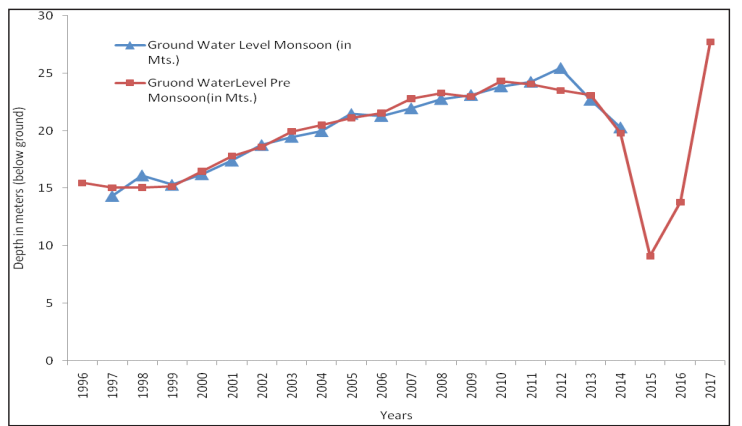

Fig. 1: Ground water level at Bawal

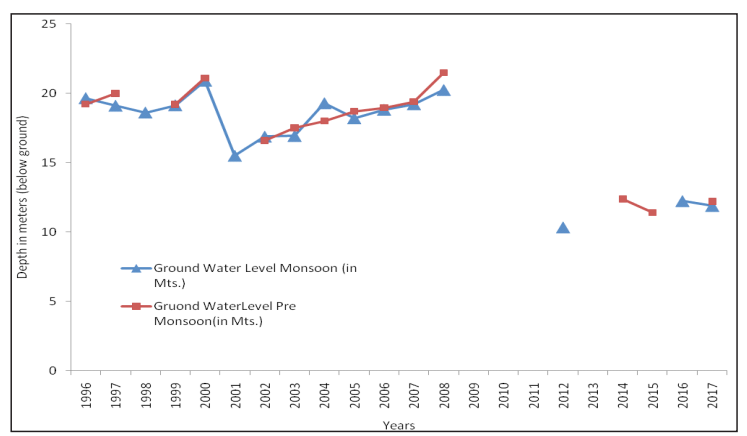

Fig. 3: Ground water levels at Khol

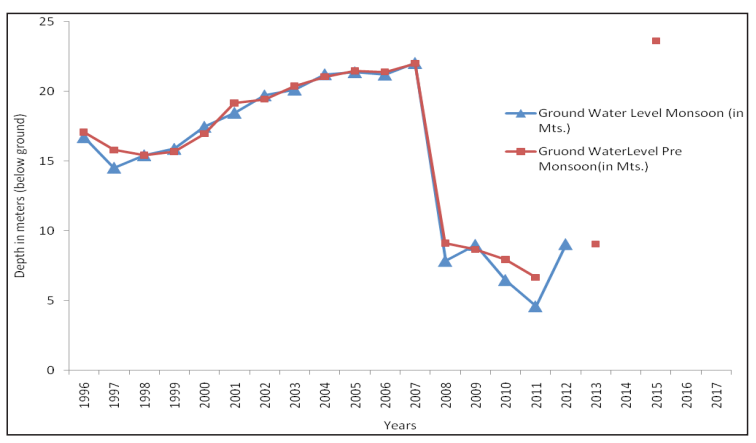

Fig. 2: Ground water levels at Jatusana

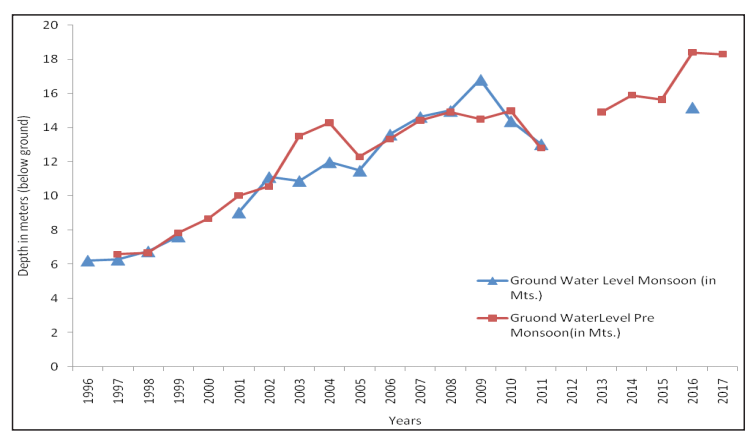

Fig. 4: Ground water levels at Nahar

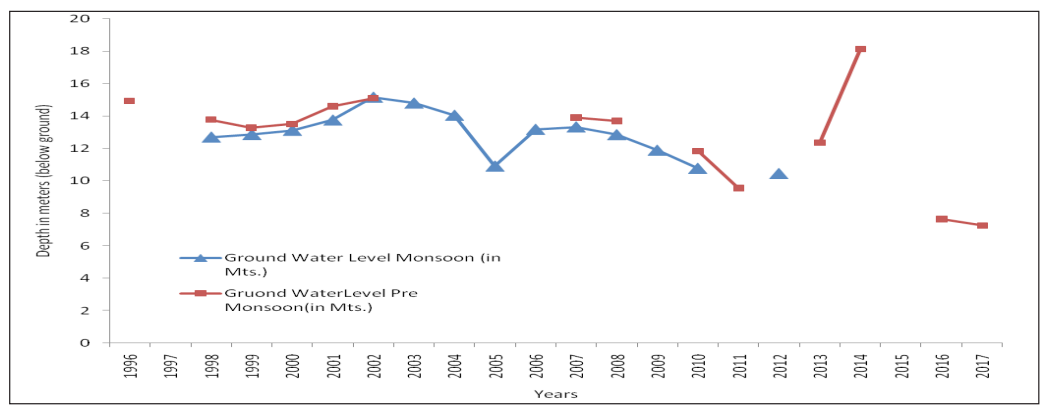

Fig. 5: Ground water levels at Rewari 


\section{Ground water status during Pre-Monsoon Period}

Average of ground water level during pre-monsoon period: The long term pre-monsoon data were analysed by average the last 2 decades (1996-2017) of water level data. During pre-monsoon ground water level in the district was ranged from 12 to 19 meters below ground level (Fig. 7). Khol (Aulant), Bawal (Karanwas) and Rewari(Sangwari) was higher water table as compared to other parts of district. Southern parts of district had higher ground water level form north parts.

Ground water level in pre-monsoon 2017: During Pre-monsoon 2017 the ground water level was found form $8 \mathrm{~m}$ to $20 \mathrm{~m} \mathrm{bgl}$ in the district (Fig. 6). In the north, ground water level was at $23 \mathrm{~m} \mathrm{bgl}$ at Jatusana station. Whereas, in south-western parts it was about $8 \mathrm{~m} \mathrm{bgl}$ around Sangwari and Karanwas stations of Rewari and Bawal blocks respectively.

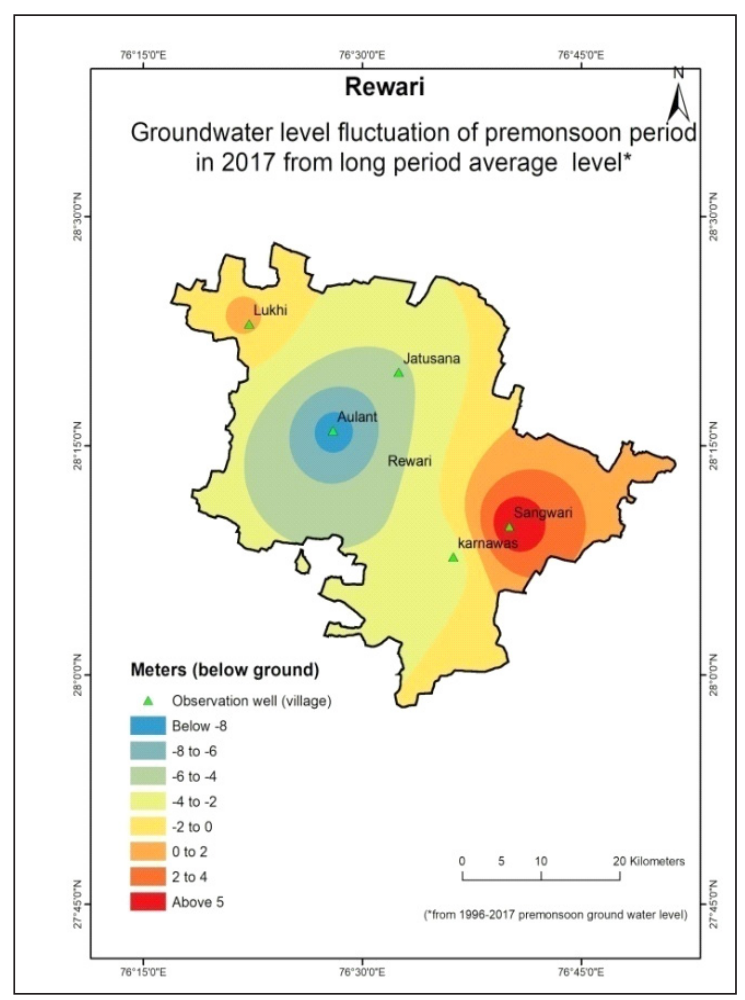

Fig. 6: Average ground water level (pre-monsoon period GW level 1996-2017)

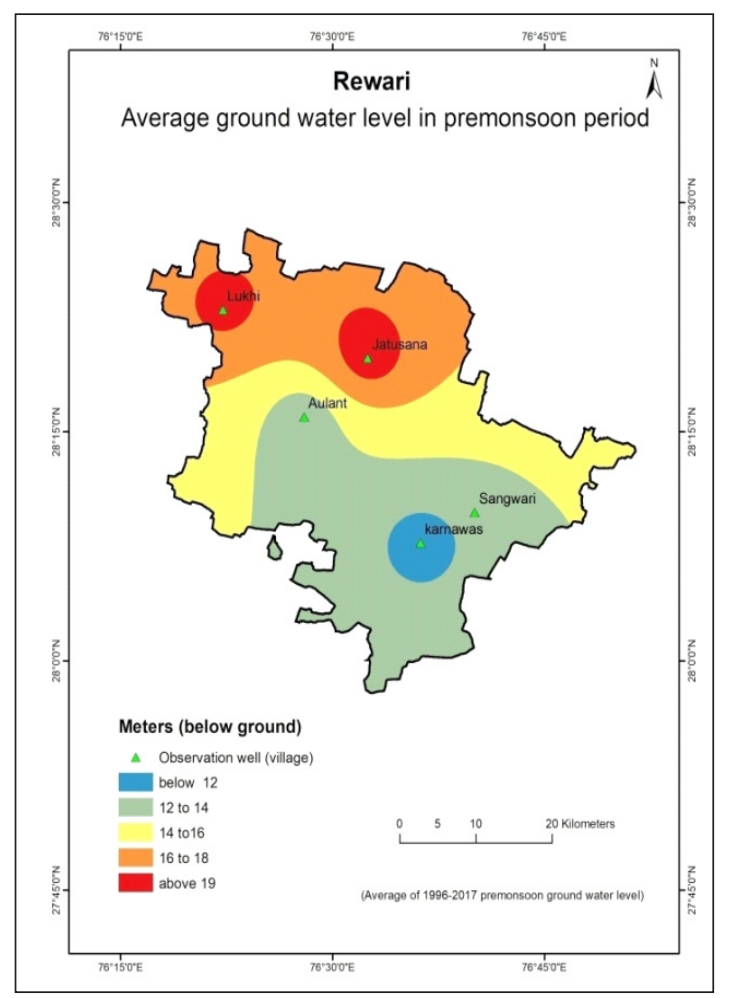

Fig.7: Ground water level during pre-monsoon 2017

Fluctuation in ground water during pre-monsoon (2017) with respect of average level:-Ground water fluctuation in pre monsoon period was found between -8 to $5 \mathrm{~m}$. District observed mix pattern of rising as well as declining trends of ground water level of pre monsoon 2017 form its long time average (19962017). Rise in water level was found in north parts and decline was in south eastern parts. Most of the blocks had rising level as shown in map (Fig. 8). 


\section{Ground water status during Monsoon Period}

Average ground water level during monsoon period:-During monsoon period, average ground water level in the district remained 10 to 16 mbelow ground. Minimum depth of Ground water was about 10 $\mathrm{m}$ around Bawal block (Karanwas station) in southern parts of Rewari district. In the north parts, ground water level was very low and depth was more than $18 \mathrm{~m} \mathrm{bgl} \mathrm{in} \mathrm{some} \mathrm{parts.} \mathrm{Overall,} \mathrm{the} \mathrm{Monsoon} \mathrm{period}$ ground water level in Rewari district was found very low (Fig. 9).

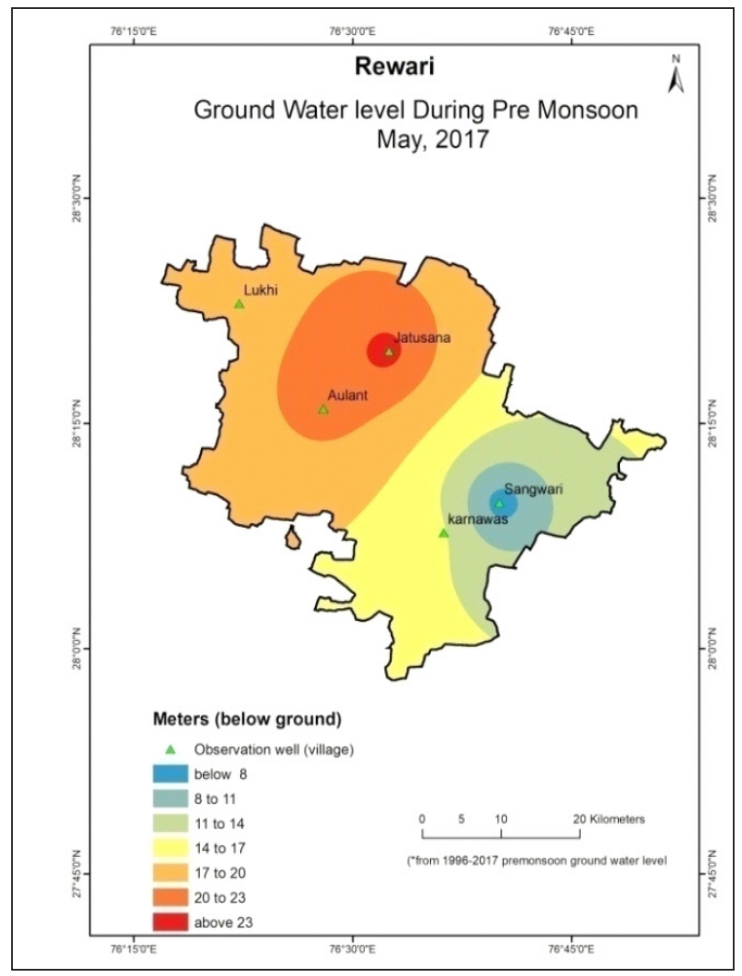

Fig. 8: fluctuations in GW level in Pre-monsoon period 2017 from average

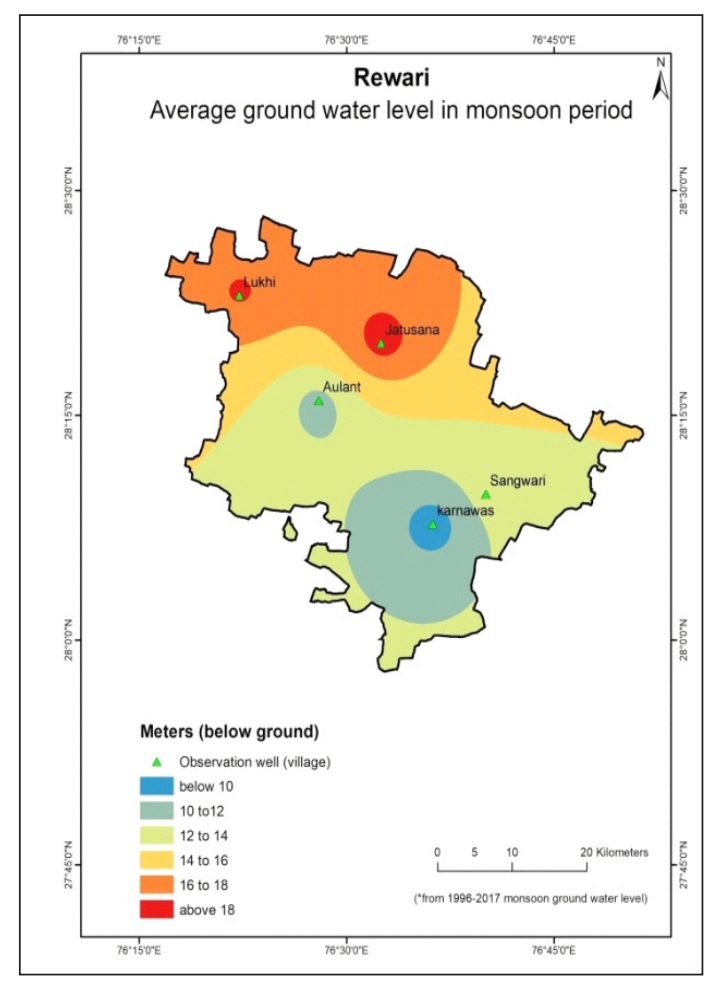

Fig. 9: Average ground water levels (monsoon period GW level 1996-2017)

Ground water level during monsoon 2017: In August, highest ground water level was found at Karanwas station at $12 \mathrm{~m} \mathrm{bgl}$. In Aulant and Jatusana ground water level was $22 \mathrm{~m} \mathrm{bgl}$. In the most of Rewari district, ground water level was found very low ranging from 12 to 20 meters or more. Southern parts of district had slightly higher water level as compared to North parts (Fig 10).

Fluctuation ground water level during monsoon (2017) with respect average level: Fluctuation of current year water (2017) level was compared with long period average water level in monsoon period for better estimation of fluctuation. Result revealed that more areas with negative values indicating the rise in water table from its normal level (Fig. 11). Central parts of Rewari district observed rising water table up to 8 meters bgl. South Eastern and north Western parts of district had declining water level of up to $2 \mathrm{~m}$ from normal. 


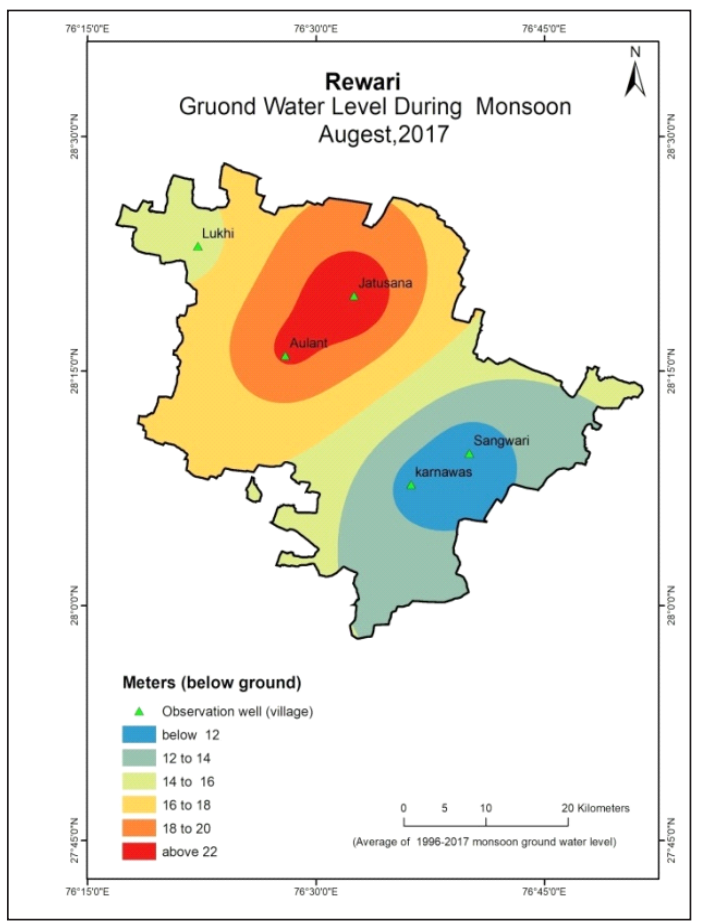

Fig. 10: Ground water level during monsoon 2017

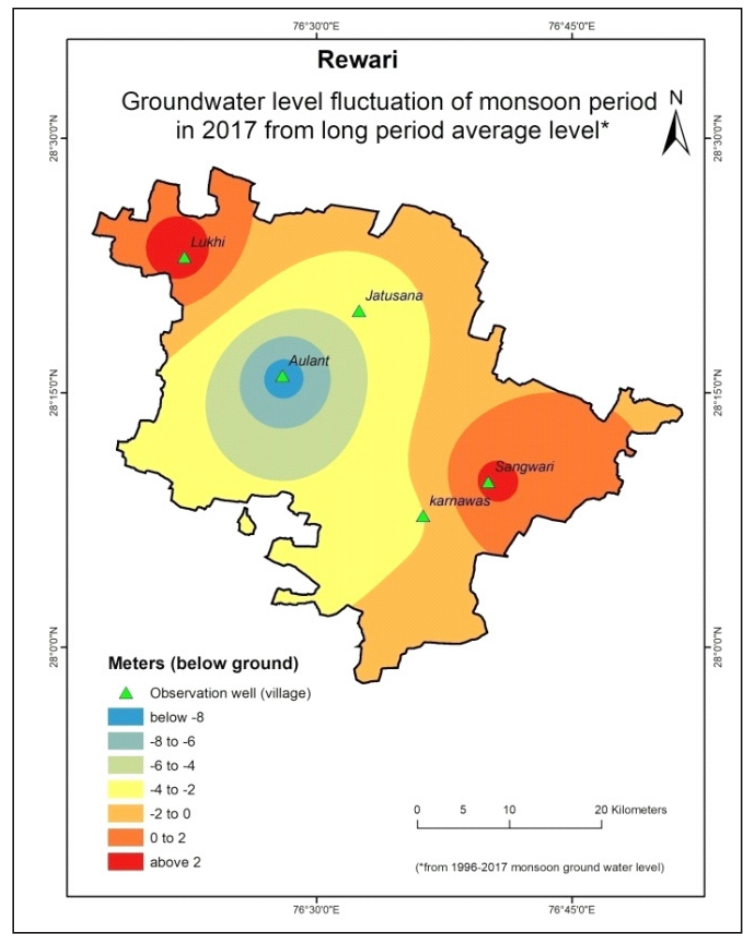

Fig. 11: Fluctuations in GW level in Monsoon period 2017 from average

Table 1: Ground Water Level (below ground water level in meters) in Rewari district

\begin{tabular}{|c|c|c|c|c|c|c|c|}
\hline Station & Block & $\begin{array}{l}\text { Groundwater } \\
\text { Pre-Monsoon } \\
2017 \text { BGL (m.) }\end{array}$ & $\begin{array}{l}\text { Groundwater } \\
\text { Monsoon } 2017 \\
\text { BGL (m.) }\end{array}$ & $\begin{array}{l}\text { Groundwater } \\
\text { Pre-Monsoon } \\
\text { 1996-2017 BGL } \\
\text { (m.) }\end{array}$ & $\begin{array}{l}\text { Groundwater } \\
\text { Monsoon 1996- } \\
2017 \text { BGL (m.) }\end{array}$ & $\begin{array}{l}\text { Fluctuation } \\
\text { Pre-Monsoon } \\
\text { BGL (m.) }\end{array}$ & $\begin{array}{l}\text { Fluctuation } \\
\text { Monsoon } \\
\text { BGL (m.) }\end{array}$ \\
\hline karnawas & Bawal & 14.18 & 11.23 & 11.08 & 9.2 & -3.1 & -2.03 \\
\hline Jatusana & Jatusana & 23.6 & 22.03 & 19.18 & 18.68 & -4.42 & -3.35 \\
\hline Lukhi & Nahar & 18.39 & 15.19 & 18.65 & 18.14 & 0.26 & 2.95 \\
\hline Aulant & Khol & 21.47 & 20.25 & 12.64 & 11.5 & -8.83 & -8.75 \\
\hline Sangwari & Rewari & 7.26 & 10.46 & 12.82 & 12.85 & 5.56 & 2.39 \\
\hline
\end{tabular}

\section{CONCLUSION}

The depth of water level ranges from 7.26 to $23.6 \mathrm{~m}$ (2017) bgl (below ground level) during pre-monsoon and 10.46 to $22.3 \mathrm{~m}$. (2017) bgl during Monsoon. The major ground water level towards the centre of the districts Jatusana and Rewari block. The Net sown area is irrigated through tube wells and canals. The minimum ground water level pre-monsoon were observed $7.26 \mathrm{~m} \mathrm{bgl}$ at Rewari block and minimum ground water level monsoon were observed $10.46 \mathrm{~m} \mathrm{bgl} \mathrm{at} \mathrm{Rewari} \mathrm{during} \mathrm{2017.} \mathrm{On} \mathrm{average} \mathrm{ground} \mathrm{water}$ table Northern part below normal level but in Southern part of Rewari is above normal level. 
In pre- Monsoon rise in water level was found in north parts and decline was in south eastern parts. Study show that in Monsoon Central parts of Rewari district observed rising water table and South eastern and north western parts of district had declining water level from normal. During monsoon period, average ground water level in the north parts was very low in Rewari district and depth was more than $18 \mathrm{~m} \mathrm{bgl}$ in some parts. During pre-monsoon ground water level in the district Khol (Aulant), Bawal (Karanwas) and Rewari (Sangwari) was higher as compared to other parts of district. Southern parts of district have higher GW level form North part of Rewari district.

\section{REFERENCES}

1. Anonymous. 2013. Groundwater information booklet, Rewari district, Haryana Central Ground water board.

2. Change, I.P.O.C. 2007. Report of the Nineteenth Session of the Intergovernmental Panel on Climate Change (IPCC) Geneva.

3. International Rice Research Institute and International Rice Research Institute. Department of Agricultural Economics, 1986. World Rice Statistics 1985. IRRI.

4. Konikow, L.F. 2011. Contribution of global groundwater depletion since 1900 to sea-level rise. Geophysical Research Letters, 38(17).

5. Saraf, A.K. and Choudhury, P.R. 1998. Integrated remote sensing and GIS for groundwater exploration and identification of artificial recharge sites. International Journal of Remote Sensing, 19(10): 1825-1841.

6. Scott, C.A. and Sharma, B. 2009. Energy supply and the expansion of groundwater irrigation in the Indus-Ganges Basin. International Journal of River Basin Management, 7(2): 119-124. 
